\title{
Pengintegrasian Pendidikan Karakter Melalui Pendekatan Pragmatik dalam Pembelajaran Bahasa Indonesia Daring
}

\author{
Integration of Character Education Through a Pragmatic Approach \\ in Online Indonesian Learning
}

\author{
Sudjalil1, Gigit Mujianto², dan Rudi3,* \\ 1,2,3 Pendidikan Bahasa Indonesia, Universitas Muhammadiyah Malang \\ Jl. Raya Tlogomas No. 246 Tlogomas, Kota Malang, Jawa Timur, Indonesia \\ 1Email: sudjalil_63@yahoo.com; Orcid: https://orcid.org/0000-0001-5902-6107 \\ 2 Email: gigit@umm.ac.id; Orcid: https://orcid.org/0000-0002-6142-1058 \\ 3,^ Email: rudikisara15@gmail.com; Orcid: https://orcid.org/0000-001-9622-8592
}

\begin{abstract}
ARTICLE HISTORY
Received 9 September 2021 Accepted 5 December 2021

Published 1 February 2022

\section{KEYWORDS}

character building, pragmatics, teacher professional education program.

KATA KUNCI

pendidikan karakter pragmatik, pendidikan profesi guru.

ABSTRACT

This study aims to describe (1) the model of integrating character education in Indonesian language learning, (2) implementing the integration of character education through a pragmatic approach in Indonesian language learning, and (3) implications of the pragmatic approach on the integration of character education in Indonesian language learning. This type of research uses case studies with a qualitative approach. The research subjects were Teacher Professional Education students in the Department of Indonesian Language Studies at the Faculty of Teacher Training and Education, University of Muhammadiyah Malang. The research data are in the form of speech data and field note data, which are sourced from faceto-face verbal interactions between teachers and students in the learning process in the classroom, with data collection techniques using observation and documentation. The data analysis technique is the Milles \& Huberman model. The results showed that: (1) the model of integrating character education in Indonesian language learning through the pragmatic approach used by the teacher is the illocutionary model; (2) the implementation of the integration of character education through a pragmatic approach in learning Indonesian is the process of communication between teachers and students based on the principle of cooperation; and (3) the implication of the pragmatic approach to the integration of character education in Indonesian language learning is the emergence of three components of good character.

ABSTRAK

Penelitian ini bertujuan mendeskripsikan, (1) model pengintegrasian pendidikan karakter dalam pembelajaran bahasa Indonesia, (2) pelaksanaan pengintegrasian pendidikan karakter melalui pendekatan pragmatik dalam pembelajaran bahasa Indonesia, dan (3) implikasi pendekatan pragmatik pada pengintegrasian pendidikan karakter dalam pembelajaran bahasa Indonesia. Jenis penelitian adalah studi kasus dengan pendekatan kualitatif. Subjek penelitian adalah mahasiswa peserta Pendidikan Profesi Guru dalam Jabatan Bidang Studi Bahasa Indonesia di Fakultas Keguruan dan IImu Pendidikan Universitas Muhammadiyah Malang. Data penelitian berupa data tuturan dan data catatan lapangan, yang bersumber dari interaksi verbal bersemuka antara guru dan peserta didik dalam proses pembelajaran di kelas. Teknik pengumpulan data dengan cara observasi dan dokumentasi. Adapun teknik analisis data dengan model Milles \& Huberman. Hasil penelitian menunjukkan bahwa: (1) model pengintegrasian pendidikan karakter dalam pembelajaran bahasa Indonesia melalui pendekatan pragmatik yang digunakan guru adalah model ilokusi; (2) pelaksanaan pengintegrasian pendidikan karakter melalui pendekatan pragmatik dalam pembelajaran bahasa Indonesia adalah jalannya proses komunikasi antara guru dan peserta didik berdasarkan prinsip kerja sama; dan (3) implikasi pendekatan pragmatik pada pengintegrasian pendidikan karakter dalam pembelajaran bahasa Indonesia berupa munculnya tiga komponen karakter yang baik.
\end{abstract}

\section{To cite this article:}

Sudjalil, S., Mujianto, G., \& Rudi, R. (2022). Pengintegrasian Pendidikan Karakter Melalui Pendekatan Pragmatik dalam Pembelajaran Bahasa Indonesia Daring. Diglosia: Jurnal Kajian Bahasa, Sastra, dan Pengajarannya, 5(1), 49-70. https://doi.org/10.30872/diglosia.v5i1.293 


\section{A. Pendahuluan}

Di masa pandemi Covid-19 ini sistem pembelajaran jarak jauh melalui sistem daring menjadi salah satu alternatif untuk memenuhi protokol kesehatan yang dipersyaratkan dalam penyelenggaraan suatu proses pembelajaran. Tentunya di samping mempunyai kelebihan, pembelajaran daring memiliki beberapa kelemahan yang tidak dimiliki oleh pembelajaran luring. Kelemahan yang nampak nyata adalah dari segi komunikasi. Komunikasi daring tidak mewakili emosi penutur, baik intonasi bicara, raut muka, maupun gerakan tubuh, sehingga maksud penutur maupun petutur merupakan hal yang relatif sulit untuk dipahami melalui komunikasi daring. Hal ini tentunya membuat tugas utama guru dalam memberikan pendidikan karakter pada peserta didik menjadi berjalan tidak optimal, terutama dalam pembelajaran bahasa Indonesia.

Melihat kondisi tersebut, maka sudah sepatutnya guru lebih mengedepankan pendekatan pragmatik dalam pengintegrasian pendidikan karakter melalui pendekatan yang lebih komunikatif dengan pemahaman makna dan konteks tuturan yang utuh. Dalam pragmatik, pengkajian bahasa didasarkan pada penggunaan bahasa bukan pada struktural semata. Konteks-konteks yang melingkupi suatu bahasa akan mendapat perhatian yang besar dalam kaitannya dengan makna yang muncul dari suatu penggunaan bahasa. Kondisi praktis tindak komunikasi menjadi pijakan utama dalam pengkajian pragmatik. Dalam hal ini, wacana-wacana yang berkaitan dengan proses komunikasi akan dikaji.

Menurut Arsjad \& Mukti (1997, p. 317), pragmatik membawa peserta didik ke dalam keterampilan menggunakan bahasa berkomunikasi praktis dalam segala situasi yang mendasari interaksi kebahasaan antara manusia sebagai anggota masyarakat. Pendapat tersebut memberikan penjelasan bahwa orientasi pragmatik adalah pada suatu komunikasi praktis, di mana pada tataran praktis muncul berbagai faktor di luar bahasa yang turut memberi makna dalam proses komunikasi tersebut yang turut membentuk karakter peserta didik.

Pendidikan karakter dalam pembelajaran bahasa Indonesia memiliki dua fungsi utama yakni membina karakter secara umum dan juga membina karakter bangsa. Oleh sebab itu, pembelajaran bahasa Indonesia berbasis karakter mutlak diterapkan dalam seluruh dimensi pendididikan. Pengintegrasian pendidikan karakter dalam pembelajaran bahasa Indonesia yang berlandaskan pembelajaraan abad 21 diharapkan dapat memberikan tantangan dan kesempatan bagi peserta didik untuk mengembangkan (1) kecakapan berpikir kritis (critical thinking skills), (2) kecakapan berkomunikasi (communication skills), (3) kecakapan berkreasi (creativity), dan (4) kecakapan berkolaborasi (collaboration). Upaya ke arah tersebut tentu saja harus dilakukan melalui beberapa saluran yang terdapat dalam proses pembelajaran bahasa Indonesia. Beberapa saluran yang dapat digunakan untuk membina karakter dalam pembelajaran bahasa Indonesia yaitu, melalui bahan ajar, melalui model pembelajaran, dan melalui penilaian otentik. Hal ini dianggap pendidikan karakter sangat memiliki peran dalam pembelajaran bahasa Indonesia (Yuningsih, Nurjaya, \& Wisudariani, 2019). Selain itu, melalui pengembangan karakter dan 
pembentukan moral dalam pembelajaran, maka dapat mewujudkan terealisasinya tujuan pendidikan nasional (Cahyati \& Arifin, 2021, p. 206).

Pengintegrasian pendidikan kakakter melalui pendekatan pragmatik dalam pembelajaran bahasa Indonesia tersebut juga menjadi suatu yang diunggulkan dalam praktik mengajar daring oleh mahasiswa Pendidikan Profesi Guru (PPG) dalam Jabatan. Hal ini dimungkinkan karena para mahasiswa tersebut dituntut untuk menerapkan pembelajaran bahasa Indonesia daring yang dapat mengembangkan karakter kritis, kreatif, komunikatif, dan kolaboratif pada diri peserta didik di sekolah masing-masing. Karakter tersebut merupakan karakter yang bersumber pada model pengintegrasian pendidikan karakter dalam pendidikan profesi guru. Dengan demikian, penelitian ini difokuskan pada model pengintegrasian pendidikan karakter, pelaksanaan pengintegrasian pendidikan karakter melalui pendekatan pragmatik, dan implikasi pendekatan pragmatik pada pengintegrasian pendidikan karakter terhadap metode dan penilaian pembelajaran bahasa Indonesia.

Terkait dengan penelitian pengintegrasian pendidikan karakter, sebelumnya sudah pernah dilakukan oleh beberapa peneliti. Pertama, penelitian oleh Zuchdi (2010) dengan fokus penelitian model pendidikan karakter yang terpadu dalam pembelajaran bidang studi yang didukung oleh pengembangan kultur sekolah, yang dapat meningkatkan baik hasil belajar murid-murid dalam bidang studi maupun perilaku mereka sesuai dengan nilai-nilai target yang dipadukan melalui pendekatan komprehensif, yang meliputi: inkulkasi (inculcation), keteladanan (modeling), fasilitasi (facilitation), dan pengembangan keterampilan (skill building). Hasil penelitian menunjukkan bahwa model pendidikan karakter yang efektif adalah yang menggunakan pendekatan komprehensif. Pembelajarannya tidak hanya melalui bidang studi tertentu, tetapi diintegrasikan ke dalam berbagai bidang studi. Metode dan strategi yang digunakan bervariasi yang sedapat mungkin mencakup inkulkasi (lawan indoktrinasi), keteladanan, fasilitasi nilai, dan pengembangan soft skills (antara lain berpikir kritis, kreatif, berkomunikasi efektif, dan dapat mengatasi masalah). Semua warga sekolah (pimpinan sekolah, semua guru, semua murid, pegawai administrasi, bahkan juga penjaga sekolah serta pengelola warung sekolah) dan orang tua murid serta pemuka masyarakat perlu bekerja secara kolaboratif dalam melaksanakan program pendidikan karakter. Tempat pelaksanaan pendidikan karakter baik di dalam kelas maupun di luar kelas dalam berbagai kegiatan, termasuk kegiatan di rumah dan dalam lingkungan masyarakat dengan melibatkan partisipasi orang tua murid.

Kedua, Yuningsih et al. (2019) melakukan penelitian yang difokuskan pada empat aspek, yaitu: (a) mengintegrasikan perencanaan pendidikan karakter, (b) mengintegrasikan pelaksanaan pendidikan karakter, (c) mengintegrasikan evaluasi pendidikan karakter, dan (d) respons siswa terhadap pengintegrasian pendidikan karakter pada pembelajaran bahasa Indonesia. Hasil penelitian menunjukkan pendidikan karakter diintegrasikan pada pembelajaran bahasa Indonesia di SMP Negeri 2 Sawan, baik dalam perencanaan, pelaksanaan, dan evaluasi pembelajaran. Pada tahap perencanaan pembelajaran, guru mencantumkan nilai-nilai karakter yang akan diintegrasikan dalam pembelajaran 
pada RPP dalam sub komponen kompetensi inti dan penilaian sikap. Pelaksanaan pembelajaran bahasa Indonesia di SMP Negeri 2 Sawan secara keseluruhan sudah mengintegrasikan nilai-nilai karakter. Nilai-nilai karakter dintegrasikan pada saat kegiatan pembelajaran berlangsung. Evaluasi pembelajaran bahasa Indonesia di SMP Negeri 2 Sawan melalui penilaian sikap. Evaluasi dilakukan melalui tes lisan dan pengamatan. Respons siswa terhadap pengintegrasian pendidikan karakter pada pembelajaran bahasa Indonesia di SMP Negeri 2 Sawan yaitu tergolong sangat positif $(38,40 \%)$, positif $(26,86 \%)$, cukup positif (22,38\%), kurang positif (5,97\%) dan sangat kurang positif $(5,97 \%)$. Hasil penelitian ini mengimplikasikan pada tahap perncanaan, guru harus memahami hakikat pendidikan karakter sehingga sub komponen pada RPP dapat diintegrasikan dengan baik dengan pendidikan karakter.

Ketiga, penelitian yang dilakukan oleh Supriadi et al. (2020) dengan fokus penelitian pada interaksi nilai karakter dalam pembelajaran keterampilan menulis. Hasil penelitian menunjukkan bahwa integrasi nilai-nilai pendidikan karakter (nilai tanggung jawab, disiplin, jujur, percaya diri, santun, kerja keras, kerjasama, menghargai, teliti dan cermat) sudah ditanamkan melalui pembelajaran bahasa Indonesia pada Siswa SMP Negeri 1 Bulukumba.

Keempat, penelitian tentang pendekatan pragmatik dalam pembelajaran bahasa Indonesia pernah dilakukan oleh Wijayanti (2018) dengan penelitian yang difokuskan pada upaya untuk mengatasi faktor internal yang diduga menjadi penyebab rendahnya tingkat minat belajar dan kemampuan membaca siswa kelas VIIIA SMP Negeri 1 Kedungbanteng Kabupaten Tegal dalam membaca, yaitu kurangnya inovasi dan kreativitas guru dalam menggunakan pendekatan pembelajaran sehingga kegiatan pembelajaran kemampuan membaca berlangsung monoton dan membosankan. Salah satu pendekatan pembelajaran yang mampu mewujudkan situasi pembelajaran yang kondusif, aktif, kreatif, efektif, dan menyenangkan adalah pendekatan pragmatik. Melalui pendekatan pragmatik, siswa diajak untuk membaca yang nyata dengan menerapkan prinsip pemakaian bahasa secara komprehensif. Hasil penelitian menunjukkan bahwa tingkat minat membaca siswa pada siklus 1 sebesar $69 \%$ dengan kategori cukup aktif meningkat menjadi $73 \%$ dengan kategori aktif pada siklus II. Kemampuan membaca yang diperoleh siswa meningkat dengan ratarata nilai pada siklus I sebesar $75 \%$ menjadi $86 \%$ pada siklus II.

Keempat penelitian yang diuraikan di atas, tidak menunjukkan hubungan atau relevansi antara pengintegrasian pendidikan karakter dan pendekatan pragmatik dalam pembelajaran bahasa Indonesia. Ketiganya mengkajinya secara terpisah. Pengintegrasian pendidikan karaktaer dititikberatkan pada sisi keterlaksanaan penanaman nilai-nilai karakter, baik dalam perencanaan, pelaksanaan, maupun evaluasi pembelajaran, serta respons siswa terhadap pengintegrasian pendidikan karakter pada pembelajaran bahasa Indonesia. Adapun penelitian terhadap pendekatan pragmatik dilakukan dalam kerangka penelitian tindakan kelas, yang dalam hal ini pragmatik dipilih sebagai 'obat' untuk meningkatkan minat dan kemampuan membaca. Oleh karena itu, penelitian ini penting dilakukan karena lebih melihat keterpaduan antara pengintegrasian pendidikan karakter dan pendekatan pragmatik. Keterpaduan 
tersebut difokuskan pada model pengintegrasian pendidikan karakter dan pelaksanaan pendidikan katakter melalui pendekatan pragmatik. Tidak cukup itu, penelitian ini juga akan mengkaji karakter baik dari implikasi pendekatan pragmatik pada pengintegrasian pendidikan karakter dalam pembelajaran bahasa Indonesia. Dengan demikian, penelitian ini tidak hanya melihat dari sisi pelaksanaannya pengintegrasian pendidikan karakter, tetapi juga mengkaji implikasi yang ditimbulkan dari pendekatan pragmatik pada pengintegrasian pendidikan karakter dalam pembelajaran bahasa Indonesia.

Berdasarkan uraian di atas penelitian ini bertujuan (1) mendeskripsikan model pengintegrasian pendidikan karakter dalam pembelajaran bahasa Indonesia, (2) mendeskripsikan pelaksanaan pengintegrasian pendidikan karakter melalui pendekatan pragmatik dalam pembelajaran bahasa Indonesia, dan (3) mendeskripsikan implikasi pendekatan pragmatik pada pengintegrasian pendidikan karakter dalam pembelajaran bahasa Indonesia.

Untuk membahas permasalahan tersebut, maka digunakan pendekatan pragmatik. Dalam bukunya yang berjudul Pragmatics, Levinson (1983, p. 5) mendefinisikan pragmatik sebagai telaah mengenai hubungan tanda-tanda dengan para penafsir. Teori pragmatik menjelaskan alasan atau pemikiran para pebicara dan penyimak dalam menyusun korelasi dalam suatu konteks sebuah tanda kalimat dengan suatu proposisi (rencana atau masalah). Dalam hal ini teori pragmatik merupakan bagian dari performansi. Pragmatik adalah telaah mengenai hubungan antara bahasa dan konteks yang tergramatisasikan atau disandikan dalam struktur suatu bahasa. Adapun dalam penelitian ini pendekatan pragmatik diorientasikan pada kajian tindak tutur, dan prisip kerja sama.

Selain itu, model pengintegrasian pendidikan karakter dalam pembelajaran merupakan wujud respons terhadap sejumlah kelemahan dalam pelaksanaan pendidikan akhlak dan budi pekerti (pendidikan karakter), terutama dalam mata pelajaran Bahasa Indonesia, telah diupayakan inovasi pendidikan karakter. Inovasi tersebut adalah sebagai berikut. Pendidikan karakter dilakukan secara terintegrasi ke dalam semua mata pelajaran. Integrasi yang dimaksud meliputi pemuatan nilai-nilai ke dalam substansi pada semua mata pelajaran dan pelaksanaan kegiatan pembelajaran yang memfasilitasi dipraktikkannya nilainilai dalam setiap aktivitas di dalam dan di luar kelas untuk semua mata pelajaran. Pendidikan karakter juga diintegrasikan ke dalam pelaksanaan kegiatan pembinaan peserta didik. Selain itu, pendidikan karakter dilaksanakan melalui kegiatan pengelolaan semua urusan di sekolah yang melibatkan semua warga sekolah (Marzuki, 2012).

\section{B. Metode}

Jenis penelitian ini adalah jenis penelitian studi kasus dengan pendekatan kualitatif, karena peneliti ingin mengetahui secara menyeluruh proses pembelajaran daring yang sedang berlangsung. Adapun subjek penelitian ini adalah delapan mahasiswa peserta Pendidikan Profesi Guru dalam Jabatan Bidang Studi Bahasa Indonesia di Fakultas Keguruan dan Ilmu Pendidikan Universitas Muhammadiyah Malang. Subjek penelitian tersebut diamati dan 
dicatat segala aktivitas pembelajarannya pada saat praktik mengajar daring di Praktik Pengalaman Lapangan (PPL) yang dimulai tanggal 21-27 Oktober 2020.

Penelitian ini mempunyai dua jenis data, yaitu data tuturan dan data catatan lapangan. Data tuturan dalam penelitian ini berupa tuturan guru peserta PPG ketika melaksanakan praktik mengajar. Adapun data catatan lapangan terdiri atas dua jenis, yaitu data catatan lapangan deskriptif dan reflektif. Data catatan lapangan deskriptif berisi tentang (a) rekonstruksi interaksi verbal dalam proses pembelajaran di kelas dan (b) perilaku guru dan peserta didik pada saat terjadi interaksi belajar-mengajar di kelas. Data catatan lapangan reflektif berisi tentang wujud tuturan guru dan gambaran tentang kondisi belajar peserta didik. Data tersebut diperoleh dari sumber data yang berupa interaksi verbal bersemuka antara guru dan peserta didik dalam proses pembelajaran di kelas. Teknik pengumpulan data dilakukan dengan cara observasi dan dukumentasi sesuai dengan fokus kajian. Adapun teknik analisis data menggunakan model Miles \& Huberman (dalam Ahmadi, 2014, p. 231). Langkah-langkah teknik analisis data meliputi, reduction, data display, dan conclusions drawing/verifying.

\section{Pembahasan}

\section{Model Pengintegrasian Pendidikan Karakter dalam Bahasa Indonesia}

Model pengintegrasian pendidikan karakter merupakan perwujudan tindak ilokusi komunikatif guru dalam menyampaikan pesan kepada peserta didik agar memberi respons seperti yang diharapkan. Apabila peserta didik memberi respons sesuai dengan pesan yang disampaikan guru, maka guru telah mencapai keberhasilan ilokusi. Ekspresi penyampaian pesan oleh guru akan memberikan ruang bagi terjadinya tidak tutur direktif, sebagai alasan peserta didik untuk melakukan tindakan. Tindak tutur direktif yang digunakan guru dalam pembelajaran bahasa Indonesia mencakup enam jenis tuturan, yaitu requestives, questions, requirements, probibitives, permissives, dan advisories.

Pembelajaran diawali dengan advisories dari guru, yang memberi dorongan agar peserta didik tetap bersemangat dalam mempelajari materi. Di samping itu, guru juga mengingatkan agar peserta tetap giat dalam belajar, tidak boleh malas.

(1) Guru: Nah, hari ini kita akan melakukan pembelajaran bahasa Indonesia seperti biasanya karena masih pandemi, kita tidak bisa bertatap muka secara langsung di sekolah, kita hanya bisa melakukan pembelajaran daring. Tapi, Bu Dyah harap kita tetap semangat dalam mempelajari materi ya.. Kita tidak males-malesan, tetap giat dalam belajar.

Advisories diberikan guru untuk memotivasi semangat peserta didik yang sedang mengikuti pembelajaran bahasa Indonesia daring, tidak bisa bertemu langsung dengan guru karena situasi masih pandemi. Setelah situasi kelas kondusif, guru menyampaikan requestives kepada peserta didik.

Requestives yang berupa ekspresi keingingan guru agar peserta didik segera melakukan sesuatu muncul pada awal pembelajaran. Ekspresi ini 
digunakan guru dengan meminta salah seorang peserta didik untuk memimpin doa sebelum memulai kegiatan pembelajaran.

(2) Guru: Nah, kita ketemu, ketemu lagi dengan cara yang sama, kita melalui pembelajaran secara virtual, nah sebelum pembelajaran kali ini dimulai Bu Dyah minta tolong Marda untuk memulai doa.

Peserta Didik (Marda): Untuk mengawali kegiatan hari ini, ada baiknya kita untuk mewajibkan berdoa terlebih dahulu sesuai dengan keyakinan masing-masing, berdoa mulai...

Guru mengekspresikan keinginannya dengan menggunakan verba "minta tolong". Verba tersebut mengandung makna bahwa peserta didik yang ditunjuk harus segera melakukan tindakan meminpin doa seperti yang diinginkan oleh guru.

Setelah mengawali pembelajaran dengan meminta peserta didik berdoa, guru menyampaikan requirements, yaitu memberi arahan langkah-langkah pembelajaran yang akan dilaksanakan peserta didik. Arahan dimulai dengan menyampaikan platform yang akan digunakan selama pembelajaran daring dan apa yang harus dilakukan peserta didik melalui platform tersebut.

(3) Guru: Nanti, pembelajaran kita dilakukan di google classroom ya.. Jadi kalian berdiskusi dalam google classroom, kemudian Bu Dyah sudah membentuk kelompok-kelompok disana, silahkan nanti berdiskusi di ruang diskusinya masing-masing. Ini Bu Dyah share screen, biar nanti kalian tidak bingung apa saja yang harus kalian lakukan ketika di google classroom. (Guru menampilkan google classroom).

Karena kegiatan difokuskan pada metode diskusi, maka guru mengarahkan peserta didik untuk masuk pada kelompok masing-masing dan melaksanakan pembelajaran sesuai dengan langkah-langkah yang sudah ditentukan. Kesatu, peserta didik diarahkan membuka dan mengamati video untuk melakukan analisis struktur kebahasaan teks editorial.

(4) Guru: Nah ini nanti kelas kalian dalam google classroom. Seperti biasanya kalian bisa berdiskusi di kelompok-kelompok yang sudah Bu Dyah buat disini ya, kemudian nanti tugasnya adalah kalian buka tugas kelas, kemudian disini ada video pembelajaran. Nanti silahkan dibuka videonya. Silahkan nanti kalian tonton untuk mengetahui apa saja sih struktur editorial, kemudian apa saja kaidah kebahasaannya, dan bagaimana cara menganalisis struktur dan kebahasaan. Silahkan nanti kalian lihat di situ.

Kedua, peserta didik diarahkan membuka vitur petunjuk belajar. Selanjutnya, mereka diminta untuk mengunduh dan membaca teks editorial secara mandiri sebagai bahan mengisi lembar kerja peserta didik (LKPD).

(5) Guru: Setelah menonton video pembelajaran, kalian buka vitur menganalisis struktur kebahasaan. Ini ada petunjuk belajar, apa saja yang harus kalian lakukan. Kemudian disini ada file teks editorialnya, judulnya antisipasi bencana ganda. Nah ini teksnya membahas tentang covid dan banjir yang melanda Jakarta. Nah, lebih lengkap nanti silahkan dibaca sendiri, kemudian setelah membaca kalian isi lembar kerja peserta didik yang filenya nanti juga sudah ada disini. 
Dalam kegiatan awal diskusi ini guru juga menggunakan tuturan probibitives, untuk membatasi aktivitas peserta didik yang tidak relevan dengan pembelajaran daring. Di antaranya dalah mengisi LKPD secara manusla melalui buku tulis.

(6) Guru: Jadi kalian tidak perlu menulis manual di buku tulis kalian, tinggal mengunduh link LKPD kemudian kalian isikan dengan kelompok kalian, satu kelompok satu. Jadi, nanti satu kelompok hanya mengupload satu file LKPD. Nanti dituliskan anggota kelompok kalian, kemudian struktur, paragraf ke berapa, misalnya satu sampai dua dan seterusnya. Terus kaidah kebahasaan tinggal kalian tuliskan satu kalimat yang memuat kaidah kebahasaan tersebut, kalo misal tidak ada silahkan tulis tidak ada.

Jadi, peserta didik tinggal mengunduh file LKPD dan diisi bersama anggota kelompok lain. Setelah diisi, LPKD diunggah kembali. Sebagai penjelasan tambahan guru memberi petunjuk hal-hal yang perlu dilakukan peserta didik sebelum mengunggah LKPD.

Pada kegiatan diskusi, guru memberikan dorongan partisipasi pada peseta didik melalui tuturan questions menawarkan. Dengan tuturan tersebut, guru menawarkan kepada peseta didik untuk menjawab tertanyaan (Data 7). Tidak hanya bisa menjawab, guru juga meminta pesera didik memberikan solusi atas jawaban yang diberikan. Hal ini dilakukan guru dengan menggunakan tuturan questions menginterogasi (Data 8).

(7) Guru: Kemudian kaidah kebahasaannya ada empat tadi, kalimat retoris adalah kalimat tanya yang tidak merupakan jawaban, kemudian yang kedua ada kata-kata populer, kata populer ini kenapa digunakan dalam teks editorial? Ada yang tahu? Ada yang bisa menjawab?

Peserta Didik: Mudah dipahami.

(8) Guru: Kemudian, solusimu apa? Ketika harus melihat kondisi sekitar berarti kamu punya solusi dong dengan itu?

Peserta Didik (Lucky): Harus kompak sama RT/Rwnya bu.

Setelah mendapat jawaban dari peserta didik, melalui tuturan permissives, guru mengulas jawaban peserta didik dengan menegaskan dan menyatakan persetujuannya. Hal inilah yang mendorong peserta didik mengembangkan jawabannnya melalui beberapa argumentasi yang relevan dan berterima bagi guru.

(9) Guru: Nah, Lucky tadi mengatakan bahwa untuk isu tentang layang-layang itu yang sering menyangkut di kabel listrik, solusinya adalah kita harus sadar si, sadar diri, kita harus tahu tempat bermain layang-layangnya.

Peserta Didik (Lucky): Dan ada bu, ada lagi bu.

Guru: Apa?

Peserta Didik (Lucky): Kalo itu perlu dijaga bu, tidak boleh ditinggal kalo bermain layang-layang.

Guru: Oh terus..

Peserta Didik (Lucky): Takutnya nanti layang-layang ditinggal, takutnya nanti kalo jatuh tidak tau nyangkut listrik itu.. 
Guru: Oh jadi harus ditunggui ya.. Iya iya solusi yang bagus. Nah, anak-anak itu tadi contoh cara menyampaikan pendapat kita, kemudian pendapat yang bagus, opini yang bagus itu harus disertai dengan..

Peserta Didik: Fakta

Guru juga memberikan dorongan partispasi melalui requestives. Requestives ini mengekspresikan harapan guru agar peseta didik benar-benar melakukan tindakan sesuai yang diminta guru. Ekspresi ini digunakan guru ketika memfasilitasi peserta didik untuk mempresentasikan hasil diskusi kelompok masing-masing, yang diikuti dengan memberikan kesempatan pada kelompok lain untuk melengkapi dan memberi masukan atas hasil diskusi kelompok yang telah dipresentasikan.

(10) Guru: Ya, jadi yang dipilih isunya tentang layang-layang ya Rendy. Mungkin ada dari kelompok lain yang menambahkan atau memberikan masukan.

Peserta Didik: Untuk kelompok 2

Harapan guru agar kelompok lain menanggapi disampaikan dengan frasa "mungkin ada dari kelompok lain". Hal itu mengandung maksud bahwa semua kelompok berhak untuk memeberikan tanggapan atas presentasi hasil diskusi kelompok yang tampil. Setelah ditunggu beberapa saat, belum ada kelompok yang bersedia menyampaikan tanggapan. Hal ini direspons guru dengan memberikan dorongan agar kelompok menyampaikan pendapat.

(11) Guru: Berpendapat yaa.. ya..

Peserta Didik (Marda): Disitu kurang, saya ingin menambahkan dan bertanya juga, kok di bagian argumentasi nggak ada fakta pendukungnya berupa, apa.. berita yang menampilkan hal-hal tersebut seperti masalah-masalah yang dibahas di argumentasi tersebut.

Dorongan atau motivasi dari guru diwujudkan dengan kata "berpendapat" yang mendapat tekanan "yaa" sebanayak dua kali. Ini menunjukkan dorongan yang kuat agar kelompok dengan sungguh-sungguh berpartisipasi aktif dengan memerikan tanggaan terhadap hasil diskusi kelompok lain.

Berdasarkan temuan di atas, pengintegrasian pendidikan karakter dalam pembelajaran bahasa Indonesia melalui pendekatan pragmatik memilik ciri yang khas, yang berbeda dengan pendekatan lain. Dengan pendekatan pragmatik, keberhasilan menghadirkan karakter sesuai dengan nilai-nilai yang ditanamkan pada peserta didik ditentukan oleh keberhasilan ilokusi guru melalui pemilihan sejumlah tindak tutur direktif pada saat menyampaikan pesan kepada peserta didik secara intensif di dalam kelas. Pendekatan pragmatik dengan model ilokusi yang digunakan guru dalam pembelajaran bahasa Indonesia ini mencakup semua jenis tuturan direktif, yaitu requestives, questions, requirements, probibitives, permissives, dan advisories seperti yang dikemukakan oleh Searle (dalam Ibrahim, 1993, p. 16).

Hal ini berarti bahwa guru mendorong atau memotivasi peserta didik dengan dorongan atau motivasi yang bervarisi agar berbagai kemungkinan karakter yang terdapat dalam diri peserta didik dapat dimunculkan melalui respons yang 
bervariasi. Hal ini tentunya berbeda dengan model pengintegrasian pendidikan karakter yang dikemukakan oleh Zuchdi (2010) berdasarkan pendekatan integratif. Dengan pendekatan integratif guru menggunakan model terpadu yang lebih menekankan pada inkulkasi (penanaman) nilai karakter berdasarkan mekanisme pemerolehan pengalaman bermakna yang melibatkan faktor-faktor di luar kelas. Pendidikan karakter hendaknya terjadi dalam keseluruhan proses pendidikan di kelas, dalam kegiatan ekstrakurikuler, dalam proses bimbingan dan penyuluhan, dalam upacara-upacara pemberian penghargaan, dan semua kegiatan. Di samping itu, pendidikan karakter hendaknya terjadi melalui kehidupan dalam masyarakat. Orang tua, lembaga keagamaan, penegak hukum, polisi, organisasi kemasyarakatan, semua perlu berpartisipasi dalam pendidikan nilai. Oleh karena itu, hasil penelitian menunjukkan adanya pengaruh yang signifikan pengembangan kultur sekolah, pandangan warga sekolah, dan perilaku warga sekolah terhadap beberapa peningkatan perilaku yang dibatasi pada ketertiban, kedisiplinan, kejujuran, dan rasa persaudaraan.

Berbeda pula dengan hasil penelitian Supriadi et al. (2020) yang menjadikan penanaman nilai karakter sebagai sarana untuk meningkatkan keterampilan menulis karangan siswa, yaitu jujur, tanggung jawab, percaya diri, santun, kerja keras, kreatif, mandiri, teliti dan cermat. Pengintegrasian nilai-nilai karakter tersebut bertujuan untuk memberikan pemahaman konsep yang mendalam melalui pengalaman belajar autentik dan bermakna yang dalam hal ini guru mengajukan pertanyaan kepada siswa untuk mendorong aktivitas berpikirnya.

\section{Pelaksanaan Pengintegrasian Pendidikan Karakter Melalui Pendekatan Pragmatik dalam Pembelajaran Bahasa Indonesia}

Interaksi dalam praktik mengajar daring bahasa Indonesia yang dihadirkan guru dalam mengintegrasikan pendidikan karakter bertujuan meningkatkan partisipasi peserta didik dalam pembelajaran. Dengan tujuan yang demikian, proses komunikasi guru dan peserta didik harus berjalan baik. Mereka haruslah dapat saling bekerja sama. Oleh karena itu, interaksi antara guru dan peserta didik dapat dicermati berdasarkan prinsip kerja sama Grice, yang dalam pelaksanaannya guru menggunakan dua maksim, yaitu maksim kuantitas dan maksim kualitas. Pemakaian maksim tersebut tentunya mengiringi upaya guru dalam menghadirkan nilai-nilai karakter yang sangat dibutuhkan dalam meningkatkan partisipasi peserta didik dalam pembelajaran.

Melalui pemakaian maksim kuantitas, guru memberikan informasi yang cukup memadai dan seinformatif mungkin, yaitu informasi yang sungguhsungguh dibutuhkan peserta didik. Informasi yang demikian, digunakan guru untuk menyampaikan topik materi pembelajaran pada awal kegiatan pembelajaran, yang pada hari sebelumnya sudah dipelajari dengan subtopik yang berbeda. Kalimat yang disampaikan cukup singkat dengan satu inti kalimat, yaitu mempelajari teks editorial, namun sungguh-sungguh dibutuhkan peserta didik sebagai pengetahuan untuk menyiapkan diri dalam menjawab pertanyaan apersepsi yang diberikan guru. 
(12) Guru: Ya, terima kasih Rendy. Nah anak-anak hari ini kita akan mempelajari tentang teks editorial ya.. sama seperti pembelajaran kemarin, sebelumnya kita juga teks editorial. Hanya saja kalo kemarin kita mempelajari tentang apa dari ido, editorial itu? Coba Farendika!

Peserta Didik (Farendika): Tentang tesis, argumentasi sama itu bu.

Penyiapan peserta didik dengan memberikan informasi yang cukup memadai dan diikuti memberikan pertanyaan terkait pembelajaran yang telah lalu dimaksudkan untuk menggali kemampuan peserta didik sebagai modal pengetahuan untuk menerima subtopik materi pembelajaran yang akan diberikan guru. Hal ini mengisyaratkan bahwa melalui informasi dan pertanyaan tersebut, guru sedang menanamkan nilai kecerdasan pada peserta didik, karena peserta didik didorong untuk menyiapkan diri sebaik-baiknya agar dapat dapat menyelesaikan tugas secara cermat, tepat, dan cepat.

Penyiapan peserta didik juga dimaksudkan untuk mengingatkan kembali pada materi pembelajaran yang telah lalu. Dengan mengingat kembali, ilmu yang telah diperoleh tidak dilupakan sehingga bermanfaat untuk memahami fenomena yang terjadi di lingkungan masyarakat tempat peserta didik berada, termasuk pengetahuan yang disajikan dalam materi pembelajaran berikutnya. Mengingat kemanfaatan ilmu tersebut, penyiapan peseta didik juga mengisyaratkan guru sedang menanamkan nilai cinta ilmu, yakni cara berpikir, bersikap, dan berbuat yang menunjukkan kesetiaan, kepedulian, dan penghargaan yang tinggi terhadap pengetahuan.

Informasi yang cukup memadai juga digunakan guru untuk menilai kalimat temuan peserta didik terkait kalimat retoris. Penilaian yang disampaikan cukup singkat dengan satu inti kalimat, yaitu 'bukan kalimat retoris', namun sungguhsungguh dibutuhkan peserta didik sebagai pengetahuan tentang kalimat retoris yang benar melalui penilaian guru.

(13) Guru: Kemudian untuk yang nomer dua, ehh kalimat retoris kelompoknya Marda menemukan kalimat "Penanganan yang terlambat dan compang-camping bisa bikin ongkos penanganan bencana menjadi mahal dan korban berlipat ganda. Apakah menurut kelompok lain ini juga kalimat retoris?

Peserta Didik: Bukan.

Guru: Bukan, jadi kalimat retorisnya bukan kalimat ini yaa Marda dan kelompok.

Penilaian terhadap kalimat temuan peserta didik dimaksudkan untuk memberi penguatan terhadap peserta didik, apakah yang ditemukan itu benar atau tidak benar. Tentunya guru berharap peserta didik dapat menunjukkan hasil temuan sesuai dengan pemahaman terhadap fakta dan konsep yang sudah disampaikan oleh guru secara cermat, tepat, dan cepat. Hal ini mengisyaratkan bahwa melalui penilaian tersebut, guru sedang menanamkan nilai kecerdasan pada peserta didik, karena peserta didik didorong untuk menjawab secara cermat, tepat, dan cepat.

Di akhir pembelajaran, guru menyampaikan penjelasan seinformatif mungkin, mulai dari informasi tentang pertemuan pekan depan, kemudian diikuti penegasan untuk tetap semangat dan menjaga kesehatan. Setelah itu, memberi 
peringatan untuk memakai masker jika keluar rumah dan tidak perlu ke luar rumah jika tidak ada hal yang penting untuk dilakukan.

(14) Guru: Kemudian pentingnya untuk kita belajar editorial itu apa sih menurut kalian? Halo siapa yang mau menjawab?

Peserta Didik: Memberikan informasi..

Guru: Terima kasih untuk pembelajaran hari ini, Bu Dyah Akhiri ya... Kita bertemu lagi Sabtu depan. Tetap semangat, tetap jaga kesehatan. Kalau keluar pakai masker. Kalau tidak ada hal penting tidak perlu keluar rumah ya...

Peserta Didik: Yaa, siap bu siap siapa

Jadi, pemakaian maksim kuantitas oleh guru diwujudkan dalam berbagai fungsi tuturan berikut. Pertama, fungsi informasi: "Kita bertemu lagi Sabtu depan." Kedua, fungsi penegasan: "Tetap semangat, tetap jaga kesehatan." Ketiga, fungsi peringatan: "Kalau keluar pakai masker. dan Kalo tidak ada hal penting tidak perlu keluar rumah ya...."

Masing-masing fungsi tuturan tersebut memiliki maksud dan isyarat terkait dengan nilai-nilai yang sedang ditanamkan guru pada saat menutup pelajaran. Tuturan dengan fungsi informasi di atas mengandung makna bahwa pembelajaran tentang topik yang dipelajari belum tuntas, masih terdapat materi yang harus dipelajari, didiskusikan, dipresentasikan, dan dikerjakan tugas, latihan, serta soal-soal tesnya. Oleh karena itu, dengan pemberian informasi tentang pertemuan pekan depan, guru bermaksud memberitahu bahwa kegiatan pembelajaran di sekolah itu berkelanjutan, sambung menyambung, tidak bisa sekali pertemuan langsung tuntas. Perlu beberapa pertemuan untuk mencapai tujuan pembelajaran yang telah ditetapkan. Hal ini mengisyaratkan bahwa dengan informasi tersebut, guru sedang menanamkan nilai kerja keras pada peserta didik, yakni perilaku yang menunjukkan upaya sungguh-sungguh dalam menyelesaikan tugas belajar dengan sebaik-baiknya.

Tuturan dengan fungsi penegasan dimaksudkan guru untuk memberi penguatan pada peserta didik bahwa pembelajaran berkelanjutan yang membutuhkan kerja keras di dalamnya memerlukan prasyarat agar dapat dijalankan dengan baik. Prasyarat yang ditegaskan oleh guru agar dijaga peserta didik adalah semangat dan kesehatan. Hal ini mengisyaratkan bahwa dengan penegasan tersebut, guru sedang menanamkan nilai ketangguhan pada peserta didik, yakni sikap dan perilaku pantang menyerah atau tidak pernah putus asa ketika menghadapi berbagai kesulitan dalam melaksanakan tugas belajar, serta sikap dan perilaku menjaga diri dari hal-hal yang dapat mengganggu kesehatan, sehingga peserta didik mampu mengatasi kesulitan tersebut dalam mencapai tujuan pembelajaran.

Dengan tuturan yang berfungsi peringatan, guru bermaksud memberi pengarahan pada peserta didik agar di masa pandemi Covid-19 sekarang ini peserta didik selalu memakai masker jika hendak keluar rumah karena ada hal yang penting atau mendesak. Jika tidak ada hal penting, peserta didik diminta untuk tidak keluar rumah. Hal ini dimaksudkan agar peserta didik tidak banyak terlibat dalam kerumunan yang bisa membawa resiko tertular virus corona, sehingga bisa tetap sehat sebagai prasyarat untuk mengikuti pembelajaran di 
sekolah. Hal ini mengisyaratkan bahwa melalui arahan protokol kesehatan di masa pandemi, guru sedang menanamkan nilai gaya hidup sehat, yakni segala upaya untuk menerapkan kebiasaan yang baik dalam menciptakan hidup yang sehat dan menghindarkan kebiasaan buruk yang dapat mengganggu kesehatan.

Adapun interaksi dengan maksim kualitas digunakan guru untuk meneyampaikan nasihat di akhir pembelajaran setelah peserta didik bersama guru menyimpulkan pembelajaran. Dalam menyampaikan kesimpulan tersebut guru mengaitkannnya dengan tujuan pembelajaran pada hari itu, yang kemudian diikuti dengan menyampaikan tindak lanut pada pertemuan berikutnya.

(15) Guru: Dari pembelajaran hari ini, kesimpulan yang bisa diambil adalah? Peserta Didik (Agung): Misalnya menyimpulkan isu dari sebuah fakta gitu.

Guru: Tujuan pembelajaran ini kan kalian dituntut untuk bisa menyusun argumentasi dan saran terhadap isu aktual, nah untuk pertemuan selanjutnya, kita akan menulis teks editorial atau merancang teks editorial, yang terakhir Bu Dyah ingin mengingatkan kalian bahwa di sekitar kita sekarang lebih banyak jumlah penderita covid yaa, apalagi di daerah sekolah kita di Genteng Kembiritan itu banyak, kalian tetap berhati-hati, jaga protokol kesehatan, jaga kesehatan ya, nggak usah keluyuran. Jangan lupa pakek masker!

Guru menyampaikan peringatan kepada peserta didik untuk tetap berhatihati, menjaga protokol kesehatan, menjaga kesehatan, tidak keluyuran, dan tetap memakai masker. Peringatan tersebut menjadi penting untuk diperhatikan oleh peserta didik, karena sesuai dengan prinsip kerjasana, melalui maksim kualitas guru memberikan bukti terkait peringatan yang disampaikan, yaitu banyaknya jumlah penderita covid di sekitar tempat tinggal peserta didik, di wilayah tempat sekolah itu berada.

Berdasarkan temuan data di atas, pelaksanaan pengintegrasian pendidikan karakter melalui pendekatan pragmatik dalam pembelajaran bahasa Indonesia ini bukanlah tahapan-tahapan atau fase-fase kegiatan pembelajaran, tetapi lebih kepada jalannya proses komunikasi antara guru dan peserta didik melalui prinsip kerjasama yang sejalan denagan temuan Grice (dalam Rahardi, 2010), yang meliputi dua maksim, yaitu maksim kuantitas dan maksim kalitas. Komunikasi yang terjadi merupakan upaya guru dalam menanamkan nilai-nilai karakter, yang berimbas pada peningkatan keaktifan dan partisipasi peserta didik dalam pembelajaran Bahasa Indonesia. Dengan prinsip kerjasama tersebut, guru menanamkan nilai kecerdasan, nilai cinta ilmu, nilai kerja keras, nilai ketangguhan, dan nilai gaya hidup sehat.

Nilai-nilai karakter yang muncul dari proses komunikasi tersebut ini relevan dengan nilai-nilai karakter yang disarikan Direktorat Pembinaan SMP Kemdiknas RI dari butir-butir standar kompetensi lulusan (Permendiknas No. 23 Tahun 2006) dan dari nilai-nilai utama yang dikembangkan oleh Pusat Kurikulum Depdiknas RI (Pusat Kurikulum Kemdiknas, 2009). Dari kedua sumber tersebut, nilai-nilai utama yang harus dicapai dalam pembelajaran di sekolah (institusi pendidikan) di antaranya adalah sebagai kereligiusan, kejujuran, kecerdasan, ketangguhan, kedemokratisan, kepedulian, kemandirian, berpikir logis, kritis, kreatif, dan inovatif, keberanian mengambil risiko, berorientasi pada tindakan, berjiwa kepemimpinan, kerja keras, tanggung jawab, gaya hidup sehat, 
kedisiplinan, percaya diri, keingintahuan, cinta ilmu, kesadaran akan hak dan kewajiban diri dan orang lain, kepatuhan terhadap aturan-aturan sosial, menghargai karya dan prestasi orang lain, kesantunan, nasionalisme, dan menghargai keberagaman (Dit. PSMP Kemdiknas, 2010).

Temuan di atas memiliki perbedaan dengan hasil penelitian yang diperoleh Yuningsih et al. (2019) yang lebih memaknai pengintegrasian pendidikan karakter sebagai suatu tahapan pengintegrasian pendidikan karakter melalui perencanaan, pelaksanaan, sampai dengan evaluasi pembelajaran. Penelitian tersebut meyimpulkan bahwa nilai-nilai karakter telah diintegrasikan dalam semua tahapan pembelajaran, mulai dari penyusunan RPP, kegiatan pendahuluan, kegiatan inti, kegiatan penutup, sampai dengan evaluasi pembelajaran Bahasa Indonesia melalui pemberian tes lisan. Nilai-nilai karakter yang terintegrasi dalam RPP cerita fabel adalah religius, sosial, rasa ingin tahu, kreatif, jujur, disiplin, tanggung jawab, percaya diri dan sikap peduli.

Pada tahap pendahuluan guru menanamkan nilai santun dan menanamkan nilai peduli dan disiplin dengan menanyakan kabar siswa dan kehadiran siswa di kelas. Pada tahap kegiatan inti guru menanamkan nilai gemar membaca dan mandiri pada kegiatan mengamati, nilai kritis, kreatif, komunikatif dan santun pada kegiatan menanya, nilai toleransi, demokratis, kritis dan kerja sama pada kegiatan mengeksplorasi, nilai kerja sama, kritis, dan gemar membaca pada kegiatan mengasosisi, nilai menghargai prestasi pada kegiatan mengomunikasikan. Pada tahap penutup guru menanamkan nilai mandiri yaitu siswa menyimpulkan materi tanpa bantuan guru, nilai kritis terdapat pada saat guru melakukan identifikasi keunggulan dan kelemahan kegiatan pembelajaran, dan nilai toleransi pada saat siswa memberikan unpan balik dalam proses pembelajaran. Setelah melakukan tes lisan, guru memasukkan hasil evaluasi ke dalam penilaian sikap seperti jujur, disiplin, tanggung jawab, dan percaya diri.

\section{Implikasi Pendekatan Pragmatik pada Pengintegrasian Pendidikan Karakter dalam Pembelajaran Bahasa Indonesia}

Implikasi pendekatan pragmatik pada pengintegrasian pendidikan karakter adalah munculnya tiga komponen karakter baik (components of good character), yaitu (a) pengetahuan moral (moral knowing), (b) kesadaran moral (internal control), dan (c) perbuatan moral (moral action)). Kehadiran tiga komponen karakter baik tersebut menandai bahwa peserta didik mampu memahami, merasakan, dan sekaligus mampu mengerjakan nilai-nilai kebajikan. Menumbuhkan karakter baik melalui melalui pemakaian tuturan secara sinergis antara tindak tutur direktif dan prinsip kerja sama diharapkan dapat mendorong peserta didik untuk mengetahui nilai-nilai moral, memiliki kesadaran moral, dan bertindak sesuai dengan nilai-nilai moral yang diketahuinya dalam pembelajaran bahasa Indonesia di kelas.

Tiga komponen karakter baik tersebut muncul melalui pemakaian tindak tutur direktif dan prinsip kerja sama secara bervariasi. Kevariasian tersebut ditandai oleh penempatan tuturan tindak tutur direktif dan pemakaian maksim kerja sama 
oleh guru, sebelum maupun sesudah munculnya karakter baik dari peserta didik yang sedang dalam posisi memberikan respons atas nasihat dan arahan guru.

(16) Guru: Nah, hari ini kita akan melakukan pembelajaran bahasa Indonesia seperti biasanya karena masih pandemi, kita tidak bisa bertatap muka secara langsung di sekolah, kita hanya bisa melakukan pembelajaran daring. Tapi, Bu Dyah harap kita tetap semangat dalam mempelajari materi ya.. Kita tidak males-malesan, tetap giat dalam belajar. (menasihati)

Tuturan direktif menasihati dan mengarahkan memicu munculnya pengetahuan moral dari peserta didik setelah tuturan tersebut disampaikan oleh guru dalam bentuk nasihat dan memberi arahan. Guru menasihati peserta didik dengan menyuntikkan motivasi agar peserta didik tetap memiliki semangat giat belajar meskipun pembelajaran bahasa Indonesia masih dilakukan secara daring, tidak bisa bertemu langsung. Hal ini disebabkan situasi pandemi Covid19 yang belum kunjung usai sejak muncul pertama kali awal tahun 2019.

Munculnya karakter baik dari peserta didik juga didorong oleh tindakan guru pada saat sedang dalam posisi memberikan arahan atau perintah sebelum pembelajaran dimulai. Guru menunjuk salah seorang peserta didik untuk memimpin doa.

(17) Guru: Nah, sebelum melakukan pembelajaran silahkan dipimpin berdoa Syafa Rendy, biar diberi kemudahan kelancaran dalam belajar nanti. (mengarahkan)

Arahan atau perintah tersebut disampaikan guru dengan memberikan alasan pentingnya berdoa sebelum pembelajaran dimulai. Alasan yang disampaikan guru adalah agar Tuhan memberi kemudahan dan kelancaran dalam pembelajaran yang akan dilaksanakan.

Motivasi dan pemberian alasan pentingnya berdoa itulah yang kemudian menggerakkan salah seorang perserta didik yang ditunjuk untuk memimpin doa dengan diiringi munculnya karakter baik yang berupa pengetahuan moral tentang pentingnya berdoa.

(18) Peserta Didik (Rendy): Sebelum mengawali pembelajaran pada hari ini, marilah kita berdoa bersama-sama sesuai keyakinan masing-masing agar diberi kelancaran. Berdoa dimulai.

Peserta didik tersebut tidak hanya mengajak teman-temannya berdoa bersama, tetapi juga menyampaikan alasan pentingnya berdoa. Alasan yang disampaikan adalah agar Tuhan memberikan kelancaran. Variasi yang berbeda ditunjukkan guru pada saat mengakhiri pembelajaran. Guru menyampaikan tuturan direktif sekaligus juga menggunakan tuturan dengan maksim kerja sama sebelum munculnya karakter baik dari peserta didik.

(19) Guru: Terima kasih untuk pembelajaran hari ini, Bu Dyah Akhiri ya.. kita bertemu lagi Sabtu depan (mengarahkan, kuantitas), tetap semangat, tetap jaga kesehatan, kalo keluar pakai masker. Kalo tidak ada hal penting tidak perlu keluar rumah ya. (menasihati, kuantitas) 
Dari data tuturan guru di atas nampak tuturan direktif digunakan secara berpasangan dengan maksim kerja sama. Tuturan memberikan arahan dan nasihat berpasangan dengan maksim kuantitas. Hal ini berarti bahwa dalam menyampaikan arahan atau perintah dan nasihatnya, guru berupaya menggunakan tuturan yang seinformatif mungkin, sehingga mudah dipahami peserta didik dan memotivasi mereka untuk melaksanakan arahan dan nasihat untuk kembali masuk sekolah Sabtu depan dan tetap menjaga kesehatan dengan memakai masker jika keluar rumah untuk hal yang penting.

Penyampaian arahan dan nasihat yang mudah dipahami tersebut, mendapat respons berupa munculnya karakter baik dari peserta didik yang berupa tindakan moral mematuhi arahan dan nasihat guru.

(20) Peserta Didik: Yaa, siap bu siap siap.

Bentuk kepatuhan tersebut disampaikan peserta didik dengan menggunakan kata 'siap' berkali-kali (tiga kali). Ini menandakan adanya niat yang kuat untuk hadir kembali di sekolah pada Sabtu depan dan mematuhi protokol kesehatan untuk memakai masker dan berupaya maksimal menghindari kerumunan. Tindakan moral juga muncul pada saat guru menyampaikan tuturan direktif dengan bertanya mengenai kabar dan kondisi kesehatan peserta didik.

(21) Guru: Bagaimana kabar kalian hari ini? Sehat ya?

Peserta Didik: Baik alhamdulillah, baik-baik, sehat alhamdulillah.

Pertanyaan yang disampaikan guru diikuti dengan memberikan pertanyaan lanjutan untuk menggali lebih jauh tentang kabar kesehatan peserta didik merupakan wujud perhatian guru terhadap kesehatan peserta didik sebelum pembelajaran dimulai. Hal inilah yang kemudian mendorong munculnya tindakan moral dari peserta didik dengan memberi respons melalui kata-kata 'baik', 'baikbaik', 'sehat', bahkan lebih dari itu, mereka mengucapkan 'alhamdulillah'. Inilah ucapan yang mengimplikasikan tindakan moral peserta didik, karena dengan ucapan tersebut peserta didik bersyukur atas karunia kesehatan yang diberikan Allah Subhanahu wa Ta'ala.

Berbeda dengan kegiatan awal dan akhir pembelajaran, pada kegiatan inti, penempatan tuturan tindak tutur direktif dan pemakaian maksim kerja sama oleh guru dilakukan secara sinergis melalui fungsi keterampilan mengajar guru, yaitu keterampilan memberikan dorongan terhadap partisipasi peserta didik (reinforcement). Reinforcement adalah bentuk respons guru sebagai usaha mempengaruhi tingkah laku peserta didik dengan memberikan informasi ataupun balikan pada peserta didik atas perbuatannya melalui pujian atau penguatan agar mereka lebih giat berpartisipasi dalam interaksi pembelajaran.

Pada awalnya guru memberikan penguatan verbal pada jawaban peserta didik dengan mengulang atau memberi penegasan terhadap jawaban tersebut. Berdasarkan jawaban tersebut, guru kemudian menyampaikan tuturan direktif berupa permintaan pada peserta didik untuk memberikan argumentasi terhadap jawaban yang telah diberikan sebelumnya. 
(22) Guru: Sekarang isu yang berkembang itu apa si?

Peserta Didik: Layang-layang, itu bu itu layang-layang yang nyangkut kabel listrik.

Peserta Didik: Undang-undang itu lo Bu, Undang-undang cipta kerja.

Guru: Nah, dari yang tadi kalian sebutkan isu aktualnya seperti layang-layang yang mengenai kabel listrik, kemudian RUU Cipta Kerja, (reinforcement) Bu Dyah ingin tahu argumennya dari Lucky. (meminta)

Guru bermaksud menanamkan nilai-nilai kecerdasan melalui daya pikir kritis dan yang rasional melalui dorongan terhadap partispasi peserta didik dalam memberikan argumentasi terhadap jawaban dari persoalan yang diajukan. Hal inilah yang kemudian memunculkan karakter baik dari peserta didik yang berupa pengetahuan moral tentang pentingnya mengenal lingkungan sekitar tempat bermain layang-layang.

(23) Peserta Didik (Lucky): Yaa.. Pendapat saya ini bu, main layang-layang itu boleh ya bu, tapi kan harus melihat kondisi sekitar lingkungannya bu.

Menurut peserta didik, mengenal lingkungan sekitar merupakan prasyarat untuk bermain layang-layang. Oleh guru, argumen ini disusul dengan pertanyaan yang menginterogasi untuk meneguhkan pengetahuan peserta didik tentang pengenalan lingkungan sekitar. Guru bertanya terkait solusi dalam melihat kondisi lingkungan sekitar.

(24) Guru: Kemudian, solusimu apa? Ketika harus melihat kondisi sekitar berarti kamu punya solusi dong dengan itu? (bertanya, menginterogasi)

Pertanyaan yang diulang dengan memberi tekanan melalaui partikel 'dong' mengindikasikan bahwa pertanyaan itu penting untuk dijawab dan sekaligus itu merupakan bentuk dorongan terhadap partisipasi peserta didik. Hal ini memunculkan karakter baik dari peserta didik yang berupa pengetahuan moral tentang pentingnya melaksanakan kerja sama dengan pengurus RT/RW.

\section{(25) Peserta Didik (Lucky): Harus kompak sama RT/RWnya bu. (mengetahui moral)}

Jawaban singkat tersebut diberikan peserta didik secara spontan untuk merespons pertanyaan guru yang mendesak, sehingga bagi guru, jawaban tersebut perlu diuraikan lagi untuk memperjelas solusi yang diberikan dalam mengenal lingkungan sekitar ketika bermain layang-layang. Karena itu, guru memberikan penguatan berikutnya berupa pancingan tentang hal-hal yang harus dikaitkan antara satu dengan yang lain agar solusi yang diberikan lebih konkret dan masuk akal. Peserta didik diminta mengubung-hubungkan antara satu hal dengan hal yang lain, misalnya hubungan antara kersamaa dengan $R T / R W$ dan benang layang-layang yang nyakut kabel.

(26) Guru: Kemudian terkait kompak dengan RT terus benangnya ndak nggak nyangkut kabel gitu? Terus kira-kira solusinya apa? 
Dengan pertanyaan yang beruntun tersebut, barulah peserta didik memunculkan karakter baik yang tingkatannya lebih tinggi dibanding pengetahuan moral, yaitu kesadaran moral.

\section{(27) Peserta Didik: Kita sendiri harus sadar. (control internal)}

Kesadaran moral tersebut bagi peseta didik adalah kesadaran untuk memilih tempat yang sesuai dan nyaman untuk bermain layang-layang. Kesadaran ini mendapat reinforcement dari guru melalui tuturan direktif yang mengandung makna 'menyetujui' atas jawaban yang diberikan peserta didik, ketika uraiannya sudah mencapai tahap kesadaran moral.

(28) Guru: Nah, Lucky tadi mengatakan bahwa untuk isu tentang layang-layang itu yang sering menyangkut di kabel listrik, solusinya adalah kita harus sadar si, sadar diri, kita harus tahu tempat bermain layang-layangnya. (menyetujui)

Itulah karakter baik yang ditanamakan oleh guru pada peserta didik melalui dorongan terhadap partisipasi peserta didik dengan tuturan direktif menginterogasi. Solusi yang diharapkan dari permasalahan mengenai lingkungan sekitar untuk tempat bermain, tidak hanya sampai pada pengetahuan moral, tetapi harus samapai pada kesadaran moral. Hal ini kemudian memicu peserta didik untuk terus bersemangat meningkatkan partisipasi dalam diskusi kelas.

(29) Peserta Didik (Lucky): Dan ada bu, ada lagi bu..

Guru: Apa?

Peserta Didik (Lucky): Kalo itu perlu dijaga bu, tidak boleh ditinggal kalo bermain layang-layang.

Guru: Oh terus..

Peserta Didik (Lucky): Takutnya nanti layang-layang ditinggal, takutnya nanti kalo jatuh tidak tau nyangkut listrik itu.

Peningkatan tersebut terlihat dari jawaban yang sambung menyambung dari peserta didik terkait solusi yang sedang dibahas. Dari sinilah kemudian guru memberikan tuturan persetujuan dengan maksud menyimpulkan uraian solusi yang disampaikan peserta didik. Guru mengajak peserta didik untuk ikut memberikan kesimpulan terhadap permasalahan yang dibahas.

(30) Guru: Oh jadi harus ditunggui ya.. Iya iya solusi yang bagus. (menyetujui) Nah, anak-anak itu tadi contoh cara menyampaikan pendapat kita, kemudian pendapat yang bagus, opini yang bagus itu harus disertai dengan..

Peserta Didik: Fakta

Dalam memberikan kesimpulan dengan bentuk tuturan permissives yang bermakna 'menyetujui', guru menunjukkan syarat yang harus dipenuhi dalam menyampaikan pendapat, yaitu adanya fakta yang mendukung pendapat tersebut. Tuturan tersebut selanjutnya ditutup dengan kesimpulan yang dimulai dengan kata seru 'nah' yang diikuti tuturan advisories. 
(31) Guru: Benar sekali, jadi ketika kita berpendapat itu jangan asal bunyi, tapi harus ada fakta yang mendukung pendapat tersebut. (menyetujui) Nah, kemudian ketika sudah memberikan pendapat harus bisa memberikan saran atau solusi, jadi kita tidak harus mengkritik saja tapi kita harus memberikan solusinya. (menasihati)

Tuturan advisories disampaikan guru untuk memberikan nasihat pada peserta didik tentang adab dalam memberikan pendapat. Bahwa memberi pendapat tidak cukup hanya didukung oleh fakta, tetapi juga harus memberikan saran atau soluisi atas kritik yang disampaikan melalui pendapat tersebut.

Hasil analisis data di atas, menunjukkan implikasi pendekatan pragmatik pada pengintegrasian pendidikan karakter dalam pembelajaran bahasa Indonesia. Temuan implikasi ini tidak terdapat pada semua penelitian terdahulu yang sudah diuraikan di atas. Temuan ini diperoleh dari pemakaian tuturan secara sinergis antara tindak tutur direktif dan prinsip kerja sama. Kesinergisan tersebut memunculkan tiga komponen karakter yang baik (components of good character), yaitu (a) pengetahuan moral (moral knowing), (b) kesadaran moral (internal control), dan (c) perbuatan moral (moral action), yang merupakan komponen-komponen urgen dalam pendidikan karakter seperti yang disampaikan Megawangi (2007), ketika menulis tentang membangun karakter di sekolah secara efektif. Kehadiran tiga komponen karakter yang baik tersebut menandai bahwa peserta didik mampu memahami, merasakan, dan sekaligus mampu mempraktikkan 'karakter baik' yang tumbuh dari proses komunikasi antara guru dan peserta didik melalui prinsip kerjasama yang sudah dibahas pada butir 6.2. Kemunculan tiga komponen karakter baik tersebut memberi peluang pada peserta didik untuk berlatih mempraktikkan kebajikan.

Menurut William Kilpatrick (dalam Megawangi, 2007), salah satu penyebab ketidakmampuan seseorang untuk berperilaku baik, walaupun secara kognitif ia mengetahuinya, adalah ia tidak terlatih untuk melakukan kebajikan atau perbuatan-perbuatan moral (moral action). Dalam Pendidikan karakter diperlukan latihan dan praktik yang terus menerus. Karakter itu ibarat 'otot', yang akan menjadi lembek apabila tidak pernah dilatih, dan akan kuat dan kokoh kalau sering dipakai. Seperti seorang binaragawan yang terus menerus berlatih untuk membentuk ototnya. 'Otot-otot' karakter akan terbentuk dengan latihan praktik yang akhirnya menjadi kebiasaan (habit). Latihan mempraktikkan kebajikan tersebut dalam penelitian ini difasilitasi oleh guru melalui proses komunikasi intensif melalui tuturan direktif requestives, questions, requirements, probibitives, permissives, dan advisories, yang diiringi pemakaian maksimmaksim kuantitas dan maksim kualitas secara bervariasi.

Kevariasian tersebut ditandai oleh penempatan tuturan tindak tutur direktif dan pemakaian maksim kerjasama oleh guru, sebelum maupun sesudah munculnya karakter baik dari peserta didik yang sedang dalam posisi memberikan respons atas nasihat dan arahan guru. Penempatan tuturan tindak tutur direktif dan pemakaian maksim kerjasama oleh guru tersebut dipengaruhi fungsi keterampilan mengajar guru, yaitu keterampilan memberikan dorongan terhadap partisipasi peserta didik (reinforcement). Reinforcement adalah bentuk respon guru sebagai usaha mempengaruhi tingkah laku peserta didik dengan 
memberikan informasi ataupun balikan pada peserta didik atas perbuatannya melalui pujian atau penguatan agar mereka lebih giat berpartisipasi dalam interaksi pembelajaran.

\section{Penutup}

Berdasarkan hasil penelitian, dapat disimpulkan sebagai berikut. Pertama, model pengintegrasian pendidikan karakter dalam pembelajaran bahasa Indonesia melalui pendekatan pragamtik yang digunakan guru adalah model ilokusi. Dengan model ilokusi tersebut, dalam pembelajaran bahasa Indonesia guru menggunakan semua jenis tuturan direktif, yaitu requestives, questions, requirements, probibitives, permissives, dan advisories. Semua jenis tuturan tersebut merupakan perwujudan tindak ilokusi komunikatif guru dalam menyampaikan pesan kepada peserta didik, yang berdasarkan hasil penelitian telah memberi respons sesuai dengan pesan yang disampaikan guru, sehingga guru telah mencapai keberhasilan ilokusi, baik itu berupa keingingan guru agar peserta didik segera melakukan sesuatu, harapan guru agar peseta didik benarbenar melakukan tindakan sesuai yang diminta guru, maupun dorongan kepada peserta didik untuk menyampaikan pendapat.

Kedua, pelaksanaan pengintegrasian pendidikan karakter melalui pendekatan pragmatik dalam pembelajaran bahasa Indonesia adalah jalannya proses komunikasi antara guru dan peserta didik berdasarkan prinsip kerja sama. Berdasarkan hasil penelitian guru menggunakan maksim kuantitas dan maksim kalitas dalam berinteraksi dengan peserta didik untuk menanamkan nilai kecerdasan, nilai cinta ilmu, nilai kerja keras, nilai ketangguhan, dan nilai gaya hidup sehat. Pada analisis berikutnya ditemukan pemakaian maksim dan penanaman nilai-nilai karakter tersebut menjadikan keaktifan dan partisipasi peserta didik meningkat, seiring pemakaian tuturan guru yang diwujudkan dalam berbagai fungsi, baik fungsi informasi, penegasan, maupun fungsi peringatan.

Ketiga, implikasi pendekatan pragmatik pada pengintegrasian pendidikan karakter dalam pembelajaran bahasa Indonesia berupa munculnya tiga komponen karakter yang baik (components of good character), yaitu (a) pengetahuan moral (moral knowing), (b) kesadaran moral (internal control), dan (c) perbuatan moral (moral action), yang merupakan komponen-komponen urgen dalam pendidikan karakter. Berdasarkan hasil penelitian, tiga karakter baik tersebut diperoleh dari pemakaian tuturan secara sinergis antara tindak tutur direktif dan prinsip kerja sama melalui penempatan dua unsur pragmatik tersebut oleh guru, baik sebelum maupun sesudah munculnya karakter baik dari peserta didik secara bervariasi. Dengan proses komunikasi yang intensif, tuturan direktif requestives, questions, requirements, probibitives, permissives, dan advisories dan pemakaian maksim kuantitas dan maksim kualitas, guru memberi peluang pada peserta didik untuk mempraktikkan kebajikan berupa pengetahuan moral, kesadaran moral, dan perbuatan moral. 


\section{Daftar Pustaka}

Ahmadi, R. (2014). Metodologi Penelitian Kualitatif. Yogyakarta: Ar-Ruzz Media. Arsjad, M. G., \& Mukti, U. (1997). Pembinaan Kemampuan Berbicara Bahasa Indonesia. Jakarta: Erlangga.

Cahyati, J. N., \& Arifin, Z. (2021). Legenda Buka Luwur Asal-Usul Dukuh Pantaran sebagai Media Pendidikan Karakter. Diglosia: Jurnal Kajian Bahasa, Sastra, dan Pengajarannya, 4(2), 205-218. https://doi.org/10.30872/diglosia.v4i2.177

Ibrahim, A. S. (1993). Kajian Tindak Tutur. Surabaya: Usaha Nasional.

Levinson, S. C. (1983). Pragmatics. Cambridge: Cambridge University Press.

Marzuki. (2012). Pengintegrasian Pendidikan Karakter dalam Pembelajaran di Sekolah. Jurnal Pendidikan Karakter, 2(1), 33-44. http://dx.doi.org/10.21831/jpk.v0i1.1450

Megawangi, R. (2007). Pendidikan Karakter: Solusi yang Tepat untuk Membangun Bangsa. Bogor: Indonesia Heritage Foundation.

Rahardi, R. K. (2010). Pragmatik: Kesantunan Imperatif Bahasa Indonesia. Jakarta: Erlangga.

Supriadi, S., Sani, A., \& Setiawan, I. P. (2020). Integrasi Nilai Karakter dalam Pembelajaran Keterampilan Menulis Siswa. YUME: Journal of Management, 3(3), 84-93. https://doi.org/10.2568/yum.v3i3.828

Wijayanti, M. W. (2018). Upaya Meningkatkan Minat dan Kemampuan Membaca Melalui Pendekatan Pragmantik. Jurnal Penelitian Pendidikan Indonesia, 3(3), 1-8. http://www.i-rpp.com/index.php/jpp/article/view/918

Yuningsih, L. A., Nurjaya, I. G., \& Wisudariani, N. M. R. (2019). Integrasi Pendidikan Karakter pada Pembelajaran Bahasa Indonesia di SMP Negeri 2 Sawan. Jurnal Pendidikan Bahasa dan Sastra Indonesia Undiksha, 9(1), 152-162. http://dx.doi.org/10.23887/jjpbs.v9i1.20754

Zuchdi, D. (2010). Pengembangan Model Pendidikan Karakter Terintegrasi dalam Pembelajaran Bidang Studi di Sekolah Dasar. Jurnal Cakrawala Pendidikan, 1(3), 1-12. http://dx.doi.org/10.21831/cp.v1i3.224 
Sudjalil, G. Mujianto, \& Rudi 